07-020

\title{
Coerced Confessions: Self-Policing in the Shadow of the Regulator
}

\author{
Jodi L. Short \\ University of California Berkeley \\ jodishort@earthlink.net
}

Michael W. Toffel

Harvard Business School

mtoffel@hbs.edu 


\title{
Coerced Confessions: Self-Policing in the Shadow of the Regulator
}

\author{
Jodi L. Short ${ }^{*}$ \\ University of California, Berkeley \\ Michael W. Toffel \\ Harvard Business School
}

\begin{abstract}
As part of a recent trend toward more cooperative relations between regulators and industry, novel government programs are encouraging firms to monitor their own regulatory compliance and voluntarily report their own violations. In this study, we examine how regulatory enforcement activities influence organizations' decisions to self-police. We created a comprehensive dataset for the "Audit Policy," a United States Environmental Protection Agency (U.S. EPA) program that encourages companies to self-disclose violations of environmental laws and regulations in exchange for reduced sanctions. We find that facilities are more likely to self-disclose if they were recently subjected to one of several different enforcement measures and if they were provided with immunity from prosecution for self-disclosed violations.
\end{abstract}

The pitched political battles over regulation in the 1970s and 1980s, from deregulation to Reagan's vow to get government "off the back" of industry, have given way in recent years to a new wave of voluntary self-regulation programs based on a more cooperative approach between government and industry. Regulatory agencies are embracing programs that see firms as active participants in their own governance. And from the industry side, talk is increasingly about companies regulating themselves rather than trying to avoid regulation altogether. These new cooperative arrangements enjoy wide support, both from industry proponents who see selfregulation as the most flexible and efficient way to achieve regulatory goals (Murray 1999) and

* Please direct correspondence to jodishort@earthlink.net. Insightful comments by Neil Fligstein, Robert A. Kagan, David I. Levine, Howard Shelanski, and Jason Snyder are gratefully acknowledged, as are comments from participants in the Fifth Annual Strategy and the Business Environment Conference at Stanford University and the First Annual Conference on Institutional Mechanisms for Industry Self-Regulation at Dartmouth University. We appreciate the assistance of Phil Milton, Audit Policy Coordinator at the U.S. Environmental Protection Agency, for providing and interpreting some EPA data. Research funding was provided by the Center for Responsible Business and the Institute of Business and Economic Research at the Haas School of Business. Ara Abrahamian provided excellent research assistance. 
in a substantial body of academic literature touting the virtues of a more cooperative regulatory system (Bardach and Kagan 1982; Scholz 1984; Ayres and Braithwaite 1992; Gunningham and Grabowsky 1998).

This cooperative approach has inspired regulatory agencies to experiment with an array of voluntary self-regulation programs that engage firms as partners in regulatory activities, from achieving “beyond compliance”' results to policing their own noncompliance. "Beyond compliance”" programs, such as the United States Environmental Protection Agency's (U.S. EPA) Greenlights, 33/50 and Project $X L$, as well as industry initiatives such as the chemical manufacturers Responsible Care, recognize and reward firms for performance and management practices that go above and beyond what the law requires. Although there is little evidence that such programs actually improve performance (King and Lenox 2000; Welch et al. 2000; Rivera and de Leon 2004), they have been popular for their feel-good, "win-wirn" approach to regulation. However, administrative agencies can justify outsourcing more and more of their responsibilities to regulated entities only if corporations are willing to admit and correct their failures as well as tout their successes.

'Self-policing' programs push the envelope of self-regulation by shifting the burden of monitoring regulatory compliance and reporting non-compliance from the government to the private sector. Several regulatory agencies have developed self-policing programs that provide incentives to encourage companies to self-disclose their legal violations. For example, through its Hazard Analysis and Critical Control Point program, the U.S. Department of Agriculture 'Shifted much of the responsibility for safety to the plants, requiring them to identify vulnerable points in their production lines and build in steps to kill germs' (Peterson and Drew 2003:A1). In addition, the U.S. Department of Justice, the U.S. Department of Defense, and the Securities and 
Exchange Commission offer incentives including amnesty, limited liability, prosecutorial leniency, and confidentiality to encourage companies to disclose fraudulent or other illegal behavior (Fleder 1999; Duggin 2003; Medinger 2003).

These types of initiatives carry promise as well as pitfalls. On the one hand, the incentives of self-policing programs have encouraged many companies to report and correct problems that regulators never would have discovered, suggesting the possibility for real improvements in compliance. If compliance does improve at self-policing firms, regulators could shift their scarce enforcement resources to more recalcitrant companies. On the other hand, there is some evidence that self-reported violations are often minor, perhaps masking more serious unreported violations (Pfaff and Sanchirico 2004). Without any evidence that self-policing improves compliance, such programs may give industry an unprecedented and unwarranted level of control over its own regulation, raising "fears of the 'fox guarding the henhouse"(Cox 2004:28). How can regulators establish self-policing programs that balance these concerns? While the academic literature has long explored regulatory strategies that rely on some mix of voluntary reporting and governmental enforcement (e.g., Malik 1993; Kaplow and Shavell 1994; Innes 1999a, 1999b; Pfaff and Sanchirico 2000; Innes 2001), this literature is largely theoretical; little empirical evidence exists to suggest what mix most effectively encourages self-policing.

Among the first empirical studies to address self-policing behavior, this article seeks to understand how a mix of regulatory enforcement activities and statutory protections that shield companies from enforcement activities can be used to encourage organizations to police their own operations and 'turn themselves in' by self-disclosing violations. We develop a panel dataset of voluntary disclosures under the U.S. EPA's Audit Policy, which provides rich data on how violators behave when offered the option of voluntarily self-reporting. We find that, despite the 
rhetoric of cooperation surrounding self-policing programs, self-disclosures are motivated by coercive regulatory enforcement activities. Specifically, facilities were more likely to selfdisclose violations if they were recently inspected, subjected to an enforcement action, or narrowly targeted for heightened scrutiny by a U.S. EPA Compliance Incentive Program. We also find some evidence that facilities are more likely to turn themselves in when statutory immunity shields their self-disclosed violations from prosecution, but no evidence that facilities protected by audit privilege are more likely to self-disclose.

The article proceeds as follows. In the next section, we review the literature on selfpolicing and the related literature that describes how deterrence measures affect compliance. In Section 2, we describe the U.S. EPA Audit Policy, the empirical setting of our research. In

Section 3, we hypothesize how various enforcement activities and legal protections that shield self-reporters from enforcement activities may influence facilities decisions whether to selfpolice. Section 4 describes our sample and measures, and Section 5 details our empirical methods and presents our results. We discuss our results in Section 6 and offer suggestions for future research. Finally, we conclude in Section 7.

\section{LITERATURE REVIEW}

The most robust discussion of self-policing occurs in the economic literature, which models self-reporting of legal violations as a way to optimize enforcement regimes by reducing monitoring and compliance costs. Kaplow and Shavell (1994) develop a model that integrates a self-reporting component into Becker's (1968) classic theory of probabilistic law enforcement. They demonstrate that self-reporting reduces government monitoring and enforcement costs because, to the extent that violators admit their wrongdoing, "enforcement effort need not be spent identifying them’ (Kaplow and Shavell 1994:584). Innes (2001) extends this model, 
demonstrating that self-reporting optimizes the allocation of enforcement resources by lowering avoidance costs for the regulators and the regulated, and by increasing the likelihood and lowering the costs of remediation (Innes 1999a).

A few prior studies have identified factors that lead firms to self-police. Innes (2000), for example, develops an economic model which suggests that violators with a greater risk of apprehension are more likely to self-disclose their wrongdoing, but his model does not address what factors constitute and influence perception of this risk. Others have proposed how regulators can set fines to optimize compliance using self-reporting. Malik (1993), for instance, argues that an enforcement regime that relies on mandatory self-reporting of emissions data will be optimized only if regulators impose sufficiently large fines for violations that were not selfreported. Pfaff and Sanchirico (2000), demonstrate that more firms would voluntarily conduct self-audits if fines for violations were made contingent on the firm's investigative effort.

Several studies in the economic, legal, and policy literatures suggest that enforcement activities tend to discourage self-policing and self-reporting. Arguing that exposure to enforcement actions is a powerful disincentive to self-policing, some commentators call for greater statutory protections to shield would-be self-policers from legal liability for their violations (Hunt and Wilkins 1992; Goldsmith and King 1997; Grayson and Landgraf 1997; Murray 1999; Innes 2001). Innes (2001:253), for example, argues that the internal compliance audit information regulators may obtain in connection with voluntary disclosures "can place a self-reporter at risk for other civil enforcement actions.” Most commentators agree that this risk “is a major stumbling block to the widespread participation of American companies in the system” (Murray 1999:56). This logic suggests that the government must provide legal protections to mitigate exposure to enforcement activities in order to encourage firms to self-police. 
The related literature that describes how enforcement activities affect regulatory compliance, however, suggests a different result. There is broad consensus in this literature that enforcement activities improve compliance, even when they are confrontational and coercive. For example, numerous studies have shown that regulatory inspections improve compliance at targeted firms (Magat and Viscusi 1990; Braithwaite and Makkai 1991; Kuperan and Sutinen 1998; Gunningham et al. 2005; Gray and Shadbegian 2005; Shimshack and Ward 2005), including compliance with legal requirements to monitor emissions data and self-report permit violations (Laplante and Rilstone 1996; Helland 1998). And growing empirical evidence suggests that more severe deterrence measures such as penalties and enforcement actions also improve facilities regulatory compliance (Gray and Scholz 1991; Aoki and Coiffi 2000; Gunningham et al. 2005; Gray and Shadbegian 2005; Mendelhoff and Gray 2005; Shimshack and Ward 2005).

Our research expands on the existing literature in three important ways. First, we add an empirical dimension to a literature on self-policing that has been studied almost exclusively through the use of economic models. Our data on violations voluntarily self-reported under the Audit Policy provide a unique window on self-policing behavior that is notoriously difficult to observe. For example, the data enable us to test the competing claims in the literature about whether stronger enforcement encourages or deters self-policing. They also allow us to measure the incentive effects of a broad array of enforcement tools, including inspections, violation citations, enforcement actions, and targeting initiatives; our results substantially expand the prior literature's focus on setting fines at the proper level. Second, we apply insights from the compliance/deterrence literature in a novel setting to predict not whether firms will comply with law, but whether they will come clean when they have failed to comply. Finally, by examining 
how traditional deterrence strategies influence self-policing practices, we contribute to the broader debate about industry self-regulation by assessing the continued importance of government enforcement activities within a cooperative regulatory environment.

\section{THE US EPA AUDIT POLICY}

The U.S. EPA’s “Incentives for Self-Policing: Discovery, Correction and Prevention of Violations'(Audit Policy), launched in 1995, provides the empirical setting for our research. The Audit Policy seeks to encourage facilities to implement 'Systematic, objective, and periodic' environmental auditing and to develop a “documented, systematic procedure or practice which reflects the regulated entity's due diligence in preventing, detecting, and correcting violations' (U.S. EPA 1995:66708). The program provides incentives for companies to identify, voluntarily report, and correct environmental violations. In exchange, U.S. EPA promises to reduce or waive penalties that would otherwise be owed. To qualify for the Audit Policy's incentives, facilities must promptly disclose a violation to U.S. EPA, correct the violation, and take steps to prevent similar violations in the future. The Audit Policy does not apply to violations that "resulted in serious actual harm or which may have presented an imminent and substantial endangerment to public health or the environment' (U.S. EPA 1995:66709), or to violations that are similar to others the facility committed over the previous several years. Disclosures do not qualify under the Audit Policy if they are required by any law, regulation, or permit provision, if they occur in the context of an enforcement action, or if they are revealed by employee whistleblowers or discovered by third parties. Depending on whether self-disclosed violations meet all of these requirements, U.S. EPA waives $75-100 \%$ of the gravity-based (punitive) penalties associated 
with them. ${ }^{1}$ In addition, U.S. EPA assures self-disclosers that the agency will not routinely request or use internal environmental audit reports as a part of routine inspections or as the basis for civil or criminal investigations; nor will it refer self-reported violations to the U.S. Department of Justice for criminal prosecution except in rare circumstances. ${ }^{2}$

According to a dataset we constructed based on U.S. EPA databases and documents (described below), nearly 3500 facilities disclosed violations during the period 1997-2003, and many of these facilities simultaneously disclosed multiple violations. Even though many selfreporters incurred significant costs to remedy the violations they voluntarily disclosed, the majority of participants held favorable views of the program (U.S. EPA 1999). U.S. EPA also touts the program as a success: "Discovery and correction of violations under the policy have removed pollutants from the air and water, reduced health and environmental risks and improved public information on potential environmental hazards," and ensured safe management of PCBs and other hazardous wastes (U.S. EPA 1999:26745).

In an empirical analysis of self-reporting under the U.S. EPA Audit Policy, Pfaff and Sanchirico (2004) compare violations voluntarily disclosed under the Audit Policy with those discovered by U.S. EPA. The study finds that self-reported violations are significantly less severe than those routinely prosecuted by the regulator, typically involving reporting or record-

1. Gravity-based penalties are the punitive portion of a fine, set to reflect the egregiousness of the violator's wrongdoing. U.S. EPA penalties may also contain an "economic benefit" component, designed to recover any economic advantage the violations may have provided. For self-reporters who meet all of the Audit Policy's conditions, U.S. EPA waives $100 \%$ of gravity-based penalties. When violations are discovered by means other than environmental audits or due diligence efforts but all other conditions are met, $75 \%$ of gravity-based penalties are waived. U.S. EPA retains full discretion under the Audit Policy to recover any economic benefit the self-reporter gained as a result of noncompliance (Federal Register 1995).

2. Many commentators see these guidelines as insufficiently protective of self-reporters. Although it does not routinely request a firm's own internal audit reports, U.S. EPA reserves the right to seek them if it has independent reason to believe that a violation has occurred, and federal law currently provides no audit privilege for their protection. In addition, although unlikely, self-reporters place themselves at some risk of criminal charges as a result of their self-disclosures. U.S. EPA has wide discretion to determine whether a reported violation qualifies for immunity from criminal prosecution, and even when it decides to grant that protection, the criminal environmental enforcement arm of the U.S. Department of Justice, which is not bound by the Audit Policy guidelines, may take a different view on how such cases should be treated. 
keeping violations and only rarely involving more substantive environmental violations such as emissions or spills. This finding is partly an artifact of the Audit Policy's explicit exclusion from its purview those violations that result in “serious actual harm or substantial health risk'(U.S. EPA 1995). This policy naturally skews self-reporting toward violations that are less severe, in the sense that they are subject to lower penalties and do not immediately threaten human health or the environment. ${ }^{3}$ Nonetheless, record-keeping and reporting are the lynchpin of the U.S. environmental regulatory system, enabling regulators to monitor compliance and enforce substantive obligations: 'Violations of monitoring and reporting requirements should be viewed not as trivial 'paperwork violations, but rather as serious violations' (Lin 1996:761). Although the Audit Policy has limitations, it provides a useful context in which to identify the factors that encourage self-reporting, which may help regulators devise more effective incentives to increase participation.

\section{WHY DO ORGANIZATIONS TURN THEMSELVES IN?}

In this section, we hypothesize how various regulatory enforcement activities may encourage organizations to turn themselves in when they have violated regulatory requirements. To develop our hypotheses, we look to the extensive literature on how enforcement activities influence regulatory compliance. While we recognize that there may be important distinctions between the incentive structures governing decisions to comply with the law and decisions to voluntarily report a violation of the law, we believe that this literature provides relevant insights into our question because it addresses how regulated firms behave in response to a variety of legal and regulatory incentives.

The most common conceptualization of compliance behavior is grounded in deterrence

3. For examples of violations disclosed under the Audit Policy, see Federal Register (1999). 
theory, an economic model that assumes firms are rational actors that will comply with legal directives only to the extent that the costs of expected penalties exceed the benefits of noncompliance (Kagan and Scholz 1984; Andreoni et al. 1998; Spence 2001). According to deterrence theory, firms' compliance behavior is influenced both by specific deterrence'the fear engendered by the prior experience of being inspected, warned or penalized themselves’ (Thornton et al. 2005:263) and by general deterrence, or "hearing about legal sanctions against others' (Thornton et al. 2005:263; Gibbs 1986). The deterrent effect of potential sanctions is often viewed as a function of both their likelihood and their severity (e.g., Friedman 1975).

\subsection{ENFORCEMENT ACTIVITIES}

We adopt deterrence theory's premise to suggest that facilities will self-disclose compliance violations when they expect to incur more costs for hiding their violations than for disclosing them. Most prior work has focused on encouraging self-policing through incentives that lower the relative cost of self-disclosing (Malik 1993; Pfaff and Sanchirico 2000). We look instead at how the enforcement activities undertaken by regulators might encourage self-policing by shaping a facility's expectations about the likelihood and the expected costs of getting caught out of compliance.

\subsubsection{Specific Deterrence}

Prior literature has shown that enforcement activities bolster compliance with legal requirements. This includes routine monitoring activities, like inspections (Magat and Viscusi 1990; Braithwaite and Makkai 1991; Helland 1998; Kuperan and Sutinen 1998; Gunningham et al. 2005; Gray and Shadbegian 2005; Shimshack and Ward 2005); more aggressive enforcement activities like citing facilities for violations (Helland 1998); and even confrontational deterrence measures like penalties and enforcement actions (Gray and Scholz 1991; Aoki and Coiffi 2000; 
Gunningham et al. 2005; Gray and Shadbegian 2005; Mendelhoff and Gray 2005; Shimshack and Ward 2005). Each of these activities encourages compliance by raising the potential cost of non-compliance. Frequent inspections increase the likelihood that regulators will discover and penalize violations (Dimento 1989). Similarly, cited violations increase this likelihood even more, because regulators are known to target enforcement resources on facilities where inspectors have recently discovered violations (U.S. EPA 1992; Helland 1998). As a result, such facilities may expect a particularly high likelihood of apprehension (Helland 1998; Harrington 1988). Finally, facilities that have been subjected to enforcement actions may be acutely sensitive to the costs of non-compliance, both because they have incurred legal costs and often fines for their non-compliance, and because as "repeat offenders" they may face more severe consequences for future violations.

We argue that these same enforcement activities will encourage self-reporting in much the same way that they encourage compliance. Underpinning this view is our assumption that facilities self-report to bolster the regulator's confidence in their willingness to comply, with the expectation that regulators may use self-reporting not simply to learn about violations they failed to discover, but to help sort out the "good apples" from the 'bad' for purposes of targeting enforcement resources. So, for instance, facilities that are frequently inspected may expect that self-disclosing will credibly signal their commitment to compliance and encourage regulators to target their enforcement activities on other facilities that are less cooperative. Consequently, we predict that facilities subjected to more frequent inspections will be more likely to self-disclose violations.

Similarly, we expect that regulatory inspections that uncover violations will encourage facilities to self-disclose. Being cited with violations suggests that the firm has a poor 
relationship with regulators both because of its apparent unwillingness to comply and because high violation rates can result from dismayed inspectors legalistically interpreting regulations to maximize the number of violations (Aoki and Coiffi 2000). Such firms may be particularly eager to use self-reports to show their good-faith willingness to comply in an attempt to mitigate their heightened scrutiny (Helland 1998). Therefore, controlling for inspection rate, we expect organizations with more violations discovered by inspectors to be more likely to self-report regulatory compliance violations.

Finally, we predict that facilities that have been subjected to enforcement actions will be more likely to self-report. Enforcement actions are administrative or judicial proceedings that subject firms to fines, penalties, and various forms of injunctive relief, and they represent more serious compliance problems than merely cited violations. Firms with poor compliance records have been shown to go the extra mile to demonstrate compliance in order to restore their reputation with the regulator (Scholz 1984; Helland 1998; Pfaff and Sanchirico 2000), and selfreporting violations may be one way to accomplish this.

\subsubsection{General Deterrence}

Beyond their own individual experience, facilities are also influenced by enforcement activities that affect other organizations in the broader regulatory community. For example, the overall stringency of an inspection regime can influence companies' expectations that regulators will detect their violations (Epple and Visscher 1984; Cohen 1987; Cohen 2000). In addition, high-profile enforcement actions against other firms have motivated some companies to improve their compliance and monitoring practices (Thornton et al. 2005); and the fines imposed in such actions have been shown to significantly improve compliance not only at the punished firm, but also at surrounding companies (Shimshack and Ward 2005). 
One way regulators attempt to leverage general deterrence incentives is by launching targeted enforcement initiatives that single out particular industries or activities for added scrutiny (Ross 1982; Epple and Visscher, 1984; Cohen, 1987; Anderson and Talley, 1995). Such efforts are attempts to increase facilities' expectations that their violations will be discovered, thereby motivating greater compliance. For example, U.S. EPA has launched enforcement initiatives to encourage compliance and self-auditing within sectors such as steel mini-mills and chemical manufacturers. To initiate these programs, U.S. EPA often sends letters to companies in the targeted group warning that facilities that fail to participate "will be targeted for potential enforcement inspections," which "could result in an enforcement action.` In addition, U.S. EPA releases a list of "National Priority” sectors where it will target enforcement resources. Such campaigns are designed to encourage compliance by increasing these targeted facilities' perceived likelihood of getting caught. We expect that this heightened expectation of getting caught will encourage organizations facing general deterrence initiatives to self-disclose violations.

\subsection{STATUTORY PROTECTION FROM ENFORCEMENT}

While the compliance/deterrence literature suggests that enforcement activities will encourage self-policing, many have suggested that facilities must be shielded from the risk of enforcement actions in order to encourage self-policing (Hunt and Wilkins 1992; Murray 1999; Innes 2001). This argument has prompted many states to enact statutory protections of two kinds: (1) audit privilege laws that prevent state regulatory agencies and private parties from obtaining any documents produced in connection with an internal environmental audit or using them in court against a voluntary discloser; and (2) immunity statutes that shield companies from

4. U.S. EPA's “Show Cause Letter Regarding EPCRA Section 312 Sector Agreement” and "Asphalt letter," both obtained via a Freedom of Information Act request. 
prosecution for violations they voluntarily self-disclose. States have taken a variety of approaches, with some providing one or both of these protections and others providing none.

Many scholars argue that companies will not self-police by conducting compliance audits and self-disclosing violations unless they can be assured that materials produced in connection with these internal reviews will remain strictly confidential (Hunt and Wilkins 1992; Goldsmith and King 1997; Grayson and Landgraf 1997; Murray 1999; Innes 2001). State audit privilege laws prevent the disclosure of this material and protect against a variety of disclosure risks, including criminal liability, exposure to citizen suits, overlapping state liability, and bad publicity. There is broad consensus that, '[u]nless current law and existing policies are modified to broaden confidentiality privileges,...powerful disincentives to self-examination will remain" (Hunt and Wilkins 1992:366).

State immunity statutes provide a different way of protecting voluntary disclosers, preserving state regulators' access to all relevant information about a firm's compliance, but preventing them from penalizing a company for violations it voluntarily discloses (Kaisersatt 1996; Gardner 2003). In many ways, state immunity statutes simply mimic the protection that most federal voluntary programs already provide. However, this protection can be important because facilities often face overlapping state and federal regulatory obligations, and without immunity, information disclosed under a federal voluntary program could later be used in a prosecution by state regulators.

A large survey of U.S. manufacturing facilities found that nearly a third of those that were not conducting internal audits declined to do so based on a concern that regulators might obtain an audit report and use it against them (Morandi 1998). A majority of such facilities located in states without immunity or privilege laws claimed they would begin conducting 
internal audits if their state passed such laws (Morandi 1998). These theoretical arguments and claims by company representatives have been subjected to little empirical evaluation. We remedy this by examining the extent to which state-level audit privilege and immunity statutes encourage organizations to self-report compliance infractions.

\section{DATA AND MEASURES}

\subsection{SAMPLE}

Our sampling approach attempts to surmount a major limitation of much of the empirical research on self-regulation. Because the homogeneity of interests among similar firms fosters bonds that can facilitate effective self-monitoring (Rees 1994), many empirical studies of selfregulation have focused on a single industry or, in some cases, a handful of firms (e.g., Rees 1994; King and Lenox 2000; Welch et al. 2000; Gunningham et al. 2003; Rivera and de Leon 2004). Our sample spans a wide variety of industries, which should produce more generalizable insights about the dynamics of industry self-regulation.

Our sampling frame includes manufacturing and other facilities engaged in pollutionintensive industries that are subject to the U.S. EPA's Toxic Release Inventory (TRI) program, as well as two federal regulations that apply to a broad array of industries: the U.S. Clean Air Act (CAA) and the U.S. Resource Conservation and Recovery Act (RCRA). This frame yields a sample of 17,464 facilities during our study period of 1997 to 2003 that have 10 or more employees, manufacture or use significant amounts of toxic chemicals (typically 10,000 pounds), emit air pollutants beyond CAA regulatory thresholds, and generate, manage, store, or treat hazardous waste. 


\subsection{MEASURES}

We measured voluntary disclosure as a dummy variable, coded 1 for a facility in a year when it disclosed a compliance violation in conjunction with the U.S. EPA Audit Policy. We constructed the most comprehensive dataset possible of Audit Policy self-disclosures. We began by merging data from the U.S. EPA Integrated Compliance Information System (ICIS) database and the (hardcopy) U.S. EPA Audit Policy Docket. Discussions with U.S. EPA revealed that both these sources were incomplete, which led us to also include facilities who participated in Compliance Incentive Programs by self-disclosing violations under the Audit Policy. We present the annual number of facilities self-disclosing violations to the Audit Policy in Table 1.

\section{<<COMP: Place Table 1 about here>>}

We measure the specific deterrence effect of inspections and inspector-discovered violations using data from U.S. EPA’s Resource Conservation and Recovery Act Information (RCRAInfo) database and Aerometric Information Retrieval System/AIRS Facility Subsystem (AIRS/AFS) database. ${ }^{5}$ We measure whether a facility had an enforcement action using data obtained from U.S. EPA's ICIS database. In our empirical model for the selection analysis, we lagged each of these variables one year.

We considered two types of general deterrence. First, we considered the facilities and sectors that were targeted by U.S. EPA Compliance Incentive Programs that encouraged them to review their compliance status and consider self-disclosing violations via the Audit Policy. U.S. EPA typically announces Compliance Incentive Programs in its Enforcement Alert newsletter or on its website, and it often contacts affected facilities directly by letter. Facilities may also learn about these programs through trade associations that have partnered with U.S. EPA for the

5. To reduce the potential influence of outliers, for each of these variables we recoded values above the 99th percentile to the 99th percentile value. 
initiative. We gathered data about Compliance Incentive Programs through a Freedom of Information Act request. ${ }^{6}$ The second form of general deterrence we considered is U.S. EPA's announcement of National Priority Sectors. U.S. EPA announces its two-year priorities in Memoranda of Agreement, which we obtained from the agency's website. ${ }^{7}$ Because U.S. EPA typically announces its National Priorities the year before they take effect, we considered facilities to be targeted by National Priorities for three years: the announcement year and the two years they were in effect. Because some National Priorities are implemented through Compliance Incentive Programs, we created three dummy variables to reduce multicollinearity:

(1) National Priority Sector and Compliance Incentive Program Target; (2) National Priority Sector only; and (3) Compliance Incentive Program Target only. We also created a postCompliance Incentive Programs target dummy variable, coded 1 in years after a facility was first targeted by a Compliance Incentive Program and zero otherwise, to measure any lasting effects such targeting might have.

We created two dummy variables to indicate whether a facility was located in a state that provided audit privilege and/or immunity in a given year. We constructed these variables using data from Morandi (1998), U.S. EPA's Audit Policy website, and a private web service run by the Auditing Roundtable. We resolved any inconsistencies by referring to the actual statutory language in LEXIS-NEXIS state statutory databases. Our coding of this variable is presented in the Appendix, Table A1.

Surrounding communities have been shown to influence facilities' compliance behavior

6. Compliance Incentive Programs that affected our sample include the National Iron \& Steel Mini-mills Program, National Industrial Organic Chemicals Program, National Nitrate Compounds Program, Region 1 Chemical Industry Program, and Region 5 Iron \& Steel Mini-mill Program.

7. National Priority sectors in our sample include chemical preparation (1998-1999), coal-fired power plants (1996-1999), industrial organic chemicals (1996-1999), iron and basic steel products (1996-1999), metal electroplating and coating (2000-2003), mining (1996-1997), petroleum refining (1996-2003), plastic materials and synthetics (1996-1997), primary nonferrous metals (1996-1999), printers (1996-1997), and pulp mills (1996-1999) (http://www.epa.gov/compliance/data/planning/shortterm.html [last updated March 17, 2005]). 
(Hamilton 1999; Kagan et al. 2003; Shapiro 2005), and thus communities may also influence facility decisions to self-report violations. To control for this, we include three variables that capture the community's demographic characteristics and potential ability to organize politically:

log population density, calculated as the average number of residents per square mile in the facility's Census Tract based on the U.S. Census Bureaưs 2000 Decennial Census; ${ }^{8}$ (2) log household income within each facility's Census Tract using data from the 2000 Decennial Census; and (3) voter turnout, calculated as the proportion of residents aged 18 and over in the facility's county who voted for a presidential candidate in the 2000 general election, ${ }^{9}$ as a proxy for a community's level of political awareness and participation (Hamilton 1993, 1999). County population data were obtained from the 2000 Decennial Census, and voting data were obtained from Lublin and Voss (2001) for all states except Alaska.

We also control for facility size, which is commonly associated with compliance behavior (Edelman 1990; Brehm and Hamilton 1996). We estimate facility size as the nationwide average revenues per establishment within each 4-digit SIC Code, using data from the 1997 Economic Census, the most recent year available. To control for potential differences between industries, we create dummy variables for each 2-digit SIC Code to reflect the facility's industry. We created dummies for the ten EPA Regions to control for differences in their inspection coverage and enforcement strategies (U.S. GAO 2000). ${ }^{10}$ Because the prevailing ideology of U.S. Circuit Courts has been shown to influence company decisions (Guthrie and

8. To reduce the influence of outliers, we recoded values outside the 1st and 99th percentiles to these limits, and took the log of the trimmed values.

9. To reduce the potential influence of outliers, we recoded values above the 99th percentile to the 99th percentile value. The county is the smallest geographic unit for which we could locate voting data across the United States.

10. To better control for differences between state regulators' strategies, resources, and reputations, we also ran models that included state dummies, with and without state $\times$ year interactions. While these prevent us from including our statutory immunity and audit privilege variables, the significance and magnitude of the coefficients on the remaining variables were nearly identical. 
Roth 1999), we control for the possibility that the composition of the federal judiciary might affect the self-reporting decisions of companies. Judges' political ideology has been shown to affect their decision-making on a wide range of issues, including environmental issues (Revesz 2001; Malmsheimer and Floyd 2004). We use the political party of the president who appointed the judges as a proxy for the judges' own political ideology (Spence and Murray 1999), calculating the proportion of all Court of Appeals judges who served during 1990-1994 (the last year for which data are available) who were nominated by a Democratic president, using data from Zuk et al. (1996). We use the average proportion appointed by Democratic presidents for each Circuit over 1990-1994 as our measure of Federal Circuit Court ideology. Table A2 in the Appendix presents our coding of this variable.

Descriptive statistics and correlations of all variables are provided in Tables 2 and 3.

\section{<<COMP: Place Tables 2 and 3 about here>>}

\section{EMPIRICAL MODEL AND RESULTS}

We model self-disclosure as a dichotomous decision made by each facility in each year and employ a pooled probit model. In addition to enforcement actions and statutory provisions, our key independent variables, we include controls for local community characteristics, facility size, Federal Circuit Court ideology, industry, and EPA Region, and include a full set of year dummies. We employ robust standard errors clustered by facility.

\section{<<COMP: Place Table 4 about here>>}

Table 4 presents the results. To interpret the magnitude of the probit coefficients, we calculate the marginal effects based on an infinitesimal change of continuous variables, a unit change in count variables, or a discrete change in dummy variables (Column B). We evaluate these marginal effects in the context of the sample by dividing these marginal effects by the 
probability of disclosure evaluated at mean of all variables (Column C). This provides a more intuitive explanation of the marginal effects as a percentage increase or decrease in the probability of disclosure compared to the probability predicted from all variable means.

The statistically significant positive coefficients on inspections and enforcement actions support our hypothesis that specific deterrence measures encourage self-disclosure. The results suggest that an additional RCRA inspection increases the probability of self-disclosure the next year by $14 \%(p=0.020)$ and that an additional CAA inspection increases this probability by $11 \%$ $(p=0.053)$. Being subject to at least one enforcement actionta much rarer event had a much greater influence on disclosure, as our results suggest that this more than doubles the likelihood of self-disclosing the next year compared to the probability evaluated at the means of all variables $(p<0.001)$. We found no evidence that the number of RCRA or CAA violations cited in inspections had any influence on the decision to self-disclose a violation the subsequent year (controlling for inspections). In addition, the coefficients on the two violations variables are not jointly significantly different from zero $(p=0.78)$, nor is their sum $(p=0.60)$.

As for general deterrence mechanisms, facilities targeted by a U.S. EPA Compliance Incentive Program were significantly more likely to self-disclose violations. A facility targeted by both a Compliance Incentive Program and a National Priority Sector was nearly three times more likely to self-disclose a violation that year than the average facility targeted by neither program. A facility targeted by just a Compliance Incentive Program (and not a National Priority Sector) was more than twenty times more likely to self-disclose a violation that year. This kind of targeting also has lasting effects: facilities targeted by Compliance Incentive Programs, which typically provide detailed information about the Audit Policy, were four times more likely to 
self-disclose in the years after they were initially targeted. ${ }^{11}$ However, we found no evidence that facilities targeted only as part of a National Priority Sectorand not simultaneously targeted by a Compliance Incentive Program-were any more likely to self-disclose while they were considered National Priorities than facilities that were not targeted by either program.

The coefficients on the statutory immunity and audit privilege variables are positive, as predicted. While each of these coefficients is not statistically significant, their sum is not far from conventional significance levels $(p=0.17)$. This provides some indication that statutory protections encourage disclosure, but the high correlation between the immunity and privilege variables $(\rho=0.61)$ prevents us from estimating their effects precisely. Because these variables were measured at the state level, we re-ran our model clustering the standard errors by state. In this model, the immunity coefficient is statistically significant $(p=0.07)$. Its magnitude suggests that facilities are $22 \%$ more likely to self-disclose a violation in years in which states provide immunity. The coefficient on audit privilege remained insignificant regardless of the clustering technique.

\section{DISCUSSION AND FUTURE RESEARCH}

\subsection{DISCUSSION}

Our findings suggest that even as voluntary industry self-regulation programs proliferate, government still has an important role to play in encouraging self-policing. We have shown that facilities are more likely to self-report violations when they are subject to frequent inspections and targeted by focused compliance initiatives. In fact, self-reporting is not deterred even by

11. Because smaller facilities may be particularly unaware of their legal responsibilities (Brehm and Hamilton 1996), they might also have been unaware of the Audit Policy. We ran a separate model to test this, but found no evidence of this. We included three dummies for facility size (small, moderate, large) using as cutpoints the 25th and 75th percentiles of facility revenues, as well as three terms that interacted these size dummies with the post-CIP target variable. While all three coefficients on these interaction terms are positive and statistically significant, Wald tests indicate that they do not statistically differ from one another, nor do the coefficients for the interaction terms for just the large and small facilities. 
ostensibly hostile relations with regulators. Firms that recently experienced enforcement actions, which involve significant legal costs and often result in penalties and injunctive relief, are much more likely to self-disclose than those with fewer compliance problems. In addition, we find some evidence that self-disclosure is more likely when statutory immunity is provided, but no evidence that statutory audit privilege has any influence. Together, these findings support a regulatory policy that recognizes the ongoing importance of government regulation and regulators to the success of public-private regulatory partnerships.

Our findings that more inspections and enforcement actions encourage self-disclosure build on related research showing that compliance improves subsequent to both inspections (Magat and Viscusi 1990; Braithwaite and Makkai 1991; Laplante and Rilstone 1996; Kuperan and Sutinen 1998; Winter and May 2001; Gunningham et al. 2005; Gray and Shadbegian 2005) and enforcement actions (Gray and Scholz 1991; Aoki and Coiffi 2000; Gunningham et al. 2005; Gray and Shadbegian 2005; Mendelhoff and Gray 2005; Shimshack and Ward 2005). We argue that self-policing and compliance respond similarly to these deterrence incentives because participating firms use self-reports as a signal to convey a "pro-compliance" image to regulators. Because regulators consider a facility's "motivation" and "willingness to comply" when prioritizing their enforcement activities (U.S. EPA 1992), frequently inspected or prosecuted facilities may attempt to reduce their scrutiny by bolstering the regulator's confidence in their commitment to compliance.

This finding has a number of implications for the economic literature on self-policing. First, it suggests that self-reporting plays a much more complicated role in enforcement regimes than is typically recognized. Economic models conceptualize self-reporting as a way for companies to minimize the costs associated with their violations and for regulators to minimize 
enforcement costs. However, such models fail to capture potential symbolic and strategic dimensions, such as firms self-policing to improve their broader relationship with the regulator. Second, our findings that inspections and enforcement actions motivate self-disclosure raise questions about regulators ability to shift enforcement resources away from self-reporting firms, as predicted by Kaplow and Shavell (1994). This casts doubt on the ability of regulators to improve their effectiveness by relying on self-policing as a substitute for enforcement measures.

Our general deterrence results similarly suggest the ongoing importance of regulatory oversight to the success of self-policing. Self-reporting was more likely among facilities targeted by U.S. EPA Compliance Incentive Programs, which are often announced directly to targeted firms through letters or trade associations and typically offer technical compliance assistance along with the incentives of the Audit Policy. This effect lasted long after the conclusion of these particular programs, with firms previously targeted by a Compliance Incentive Program more likely to report unrelated violations in subsequent years. On the other hand, we find no evidence that facilities targeted by industry-wide U.S. EPA National Priorities were any more likely to voluntarily self-disclose violations than those in other industries. A number of factors may explain this apparent disparity. For example, facilities in National Priority Sectors might not be aware that they are a target since they are not notified directly, as typically occurs with Compliance Incentive Programs. This suggests that the more information regulated firms have about the Audit Policy, the more likely they are to participate (Brehm and Hamilton 1996). Even facilities that are aware that they are in a National Priority Sector may believe that heightened scrutiny of a broadly defined industry does not significantly increase their risk of apprehension, whereas Compliance Incentive Programs often target fewer than one hundred facilities--and in some cases as few as twenty. In any event, our results suggest an interesting convergence of 
compliance/deterrence strategies that has yet to be developed in the literature: general deterrence appears to be more effective the more targeted or “specific" it is.

Contrary to prior research showing that more inspector-discovered violations led facilities to improve their compliance (Gray and Scholz 1993; Helland 1998), we find no evidence that violation frequency increases the likelihood of self-disclosures. The mere presence of inspectors at a facility, or the threat of their arrival through targeted compliance initiatives, apparently encourages self-reporting regardless what they find once they get there. This discrepancy may result from differences between compliance and self-policing behavior: facilities previously cited for violations can only improve their standing with the regulator by cleaning up their act and complying; however, it appears that such facilities doubt they will earn the regulator's goodwill by disclosing additional violations.

We find some evidence that facilities are more likely to self-disclose violations if their state provides statutory immunity, but facilities shielded by state-level statutory audit privilege were no more likely to self-report violations. Our finding on audit privilege confirms the results of a 1998 survey, which found that facilities self-disclosed violations and conducted internal audits at the same rate regardless of whether they were protected by statutory audit privilege (Morandi 1998). Audit privilege laws may have little effect because firms have a variety of incentives to conduct internal compliance audits apart from regulatory self-policing programs (Gardner 2003). If this is correct, audit privilege shields will provide cover for corporate wrongdoing without providing countervailing benefits in the form of increased self-policing or self-reporting. These results demand a thoughtful re-examination of the many economic and policy arguments in support of secrecy for audit materials.

Audit privilege is a blunt instrument that has significant ramifications for enforcement 
and deterrence. It allows companies wide latitude to deny regulators and other potential enforcers access to important documents and testimony about non-compliance. "First, and most important, audit privileges insulate culpable agents from prosecution' (Arlen and Kraakman 1997) mot only for voluntarily disclosed violations, but potentially for others as well. U.S. EPA and environmental groups have long resisted the enactment of audit privilege laws on the grounds that they deprive the public of access to information that is crucial to health and safety and hamper regulators ability to detect and prosecute unreported wrongdoing (Bedford 1996; Woodall 1997). As the U.S. EPA said in announcing the Audit Policy, 'privilege, by definition, invites secrecy, instead of the openness needed to build public trust in industry's ability to selfpolice’' (U.S. EPA 1995:66710). Access to internal facility data is especially important in a regulatory system that has come increasingly to rely on information disclosure as its own instrument of compliance (Rechtschaffen 2004).

Our findings provide better support for the more limited protection of immunity, which “femove[s] the fear of self-incrimination' (Kesan 2000:163) while preserving public access to information that can be important to the protection of health, safety, and the environment. Most immunity statutes are narrowly tailored to protect only those violations that are promptly and voluntarily disclosed and remediated (Kaisersatt 1996), conditions also imposed by the Audit Policy. Unlike privilege, which allows violators to strategically and prophylactically shield information about their wrongdoing, immunity shields violators from potential enforcement activity only after their violations have been disclosed. It rewards self-disclosers by reducing their costs without compromising the deterrence-based enforcement regime that motivates them to come clean. 


\subsection{FUTURE RESEARCH}

Research on self-policing can be categorized into three domains: investigating the drivers of self-policing, examining the design of self-policing programs, and evaluating the effects of self-policing. By showing how government enforcement activities and statutory incentives influence self-reporting, our research examines how regulators can encourage self-policing. Future research could investigate other potential drivers, including internal corporate variables such as Board of Directors composition and the relationship between facilities and their parent companies in making compliance and self-reporting decisions. Political factors such as pressure from communities and non-governmental organizations may also play an important role in selfpolicing. In addition, future studies might focus on firms that choose not to participate in selfpolicing programs. While we have shown that agency enforcement activities encourage selfreporting, they have managed to do so for only a small minority of the regulated community. It would be useful to know whether increased enforcement would increase participation more generally, or whether non-participants require different kinds of incentives.

Research on program design has an important role to play in this regard. Self-policing programs will not be successful unless regulators properly calibrate the overall mix of incentives. We have described how one particular category of incentives influences self-reporting; future research could attend to the way firms behave in response to different kinds of incentives, including ex post and ex ante "carrots" and “sticks."

Finally, future research on self-policing should evaluate outcomes. To what extent do self-policing programs meet the objectives of regulators and participants? Do they reduce enforcement costs? Do self-policing programs have spillover effects that lead to improved compliance more generally? 


\section{CONCLUSION}

Self-regulation and self-policing have been touted as a new paradigm of regulation that trades outmoded “command-and-control' strategies for industry-directed, market-based solutions. While it is hard to deny that there are benefits to fostering more cooperative relationships between the regulators and the regulated, our research counsels caution in the face of arguments that coercive regulatory strategies are ineffective or obsolete and that government should cede to corporations the unfettered authority to regulate themselves. Offered the option of self-policing under the Audit Policy, companies were apparently willing to come clean only under the threat that they might be caught instead. It appears that, even in the era of voluntary self-policing, ‘i]nspections remain the backbone of agency compliance monitoring programs' (Wasserman 1990). Even as corporations are given an expanding role in their own governance, our study shows that the success of "voluntary" self-policing depends on the continued involvement of regulators with coercive powers. 


\section{APPENDIX}

TABLE A1

INTERNAL AUDIT STATUTORY PROTECTIONS:

PRIVILEGE AND IMMUNITY

\begin{tabular}{|c|c|c|c|c|c|c|c|c|c|c|c|c|c|c|c|c|c|c|c|}
\hline & 1995 & 1996 & 1997 & 1998 & 1999 & 200 & 200 & 200 & 2003 & & 1995 & 19 & 1997 & 1998 & 199 & 2000 & 200 & 200 & 20 \\
\hline $\mathrm{AK}$ & $\sim$ & $\sim$ & $\mathrm{I} \& \mathrm{P}$ & I\&P & $\mathrm{I} \& \mathrm{P}$ & I\&P & $I \& P$ & $\mathrm{I} \& \mathrm{P}$ & $\mathrm{I} \& \mathrm{P}$ & MT & $\sim$ & $\sim$ & I & I & I & I & I & $\sim$ & $\sim$ \\
\hline $\mathrm{AL}$ & $\sim$ & $\sim$ & $\sim$ & $\sim$ & $\sim$ & $\sim$ & $\sim$ & $\sim$ & $\sim$ & $\mathrm{NC}$ & $\sim$ & $\sim$ & $\sim$ & $\sim$ & $\sim$ & $\sim$ & $\sim$ & $\sim$ & $\sim$ \\
\hline AR & $\mathrm{P}$ & $\mathrm{P}$ & $\mathrm{P}$ & $\mathrm{P}$ & $\mathrm{P}$ & $\mathrm{P}$ & $\mathrm{P}$ & $\mathrm{P}$ & $\mathrm{P}$ & ND & $\sim$ & $\sim$ & $\sim$ & $\sim$ & $\sim$ & $\bar{\sim}$ & $\sim$ & $\sim$ & $\sim$ \\
\hline $\mathrm{AZ}$ & $\sim$ & $\sim$ & $\sim$ & $\sim$ & $\sim$ & $\sim$ & $\sim$ & $\sim$ & $\sim$ & $\mathrm{NE}$ & $\sim$ & $\sim$ & $\sim$ & I\&P & I\&P & $\mathrm{I} \& \mathrm{P}$ & I\&P & $\mathrm{I} \& \mathrm{P}$ & $\mathrm{I} \& \mathrm{P}$ \\
\hline $\mathrm{CA}$ & $\sim$ & $\sim$ & $\sim$ & $\sim$ & $\sim$ & $\sim$ & $\sim$ & $\sim$ & $\sim$ & $\mathrm{NH}$ & $\sim$ & I\&P & $\mathrm{I} \& \mathrm{P}$ & $\mathrm{I} \& \mathrm{P}$ & $\mathrm{I} \& \mathrm{P}$ & $\mathrm{I} \& \mathrm{P}$ & $I \& P$ & I\&P & $\sim$ \\
\hline $\mathrm{CO}$ & $\mathrm{I} \& \mathrm{P}$ & I\&P & I\&P & I\&P & I\&P & I\&P & I\&P & I\&P & I\&P & $\overline{\mathrm{NJ}}$ & I & I & I & I & I & I & I & I & I \\
\hline CT & $\sim$ & $\sim$ & $\sim$ & $\sim$ & $\sim$ & $\sim$ & $\sim$ & $\sim$ & $\sim$ & $\mathrm{NM}$ & $\sim$ & $\sim$ & $\sim$ & $\sim$ & $\sim$ & $\sim$ & $\sim$ & $\sim$ & $\sim$ \\
\hline DC & $\sim$ & $\sim$ & $\sim$ & $\sim$ & $\sim$ & $\sim$ & $\sim$ & $\sim$ & $\sim$ & $\mathrm{NV}$ & $\sim$ & $\sim$ & $\mathrm{I} \& \mathrm{P}$ & I\&P & I\&P & $\mathrm{I} \& \mathrm{P}$ & $\mathrm{I} \& \mathrm{P}$ & $\mathrm{I} \& \mathrm{P}$ & $\mathrm{I} \& \mathrm{P}$ \\
\hline $\mathrm{DE}$ & $\sim$ & $\sim$ & $\sim$ & $\sim$ & $\sim$ & $\sim$ & $\sim$ & $\sim$ & $\sim$ & NY & $\sim$ & $\sim$ & $\sim$ & $\sim$ & $\sim$ & $\sim$ & $\sim$ & $\sim$ & $\sim$ \\
\hline FL & $\sim$ & $\sim$ & $\sim$ & $\sim$ & $\sim$ & $\sim$ & $\sim$ & $\sim$ & $\sim$ & $\mathrm{OH}$ & $\sim$ & $\sim$ & $\mathrm{I} \& \mathrm{P}$ & $\mathrm{I} \& \mathrm{P}$ & $\mathrm{I} \& \mathrm{P}$ & $\mathrm{I} \& \mathrm{P}$ & $\mathrm{I} \& \mathrm{P}$ & $\mathrm{I} \& \mathrm{P}$ & $\mathrm{I} \& \mathrm{P}$ \\
\hline GA & $\sim$ & $\sim$ & $\sim$ & $\sim$ & $\sim$ & $\sim$ & $\sim$ & $\sim$ & $\sim$ & $\mathrm{OK}$ & $\sim$ & $\sim$ & $\sim$ & $\sim$ & $\sim$ & $\sim$ & $\sim$ & $\sim$ & $\sim$ \\
\hline$\underline{\mathrm{HI}}$ & $\sim$ & $\sim$ & $\sim$ & $\sim$ & $\sim$ & $\sim$ & $\sim$ & $\sim$ & $\sim$ & OR & $\mathrm{P}$ & $\mathrm{P}$ & $\mathrm{P}$ & $\mathrm{P}$ & $\mathrm{P}$ & $\mathrm{P}$ & $\mathrm{P}$ & $\mathrm{P}$ & $\mathrm{P}$ \\
\hline IA & $\sim$ & $\sim$ & $\sim$ & $\mathrm{I} \& \mathrm{P}$ & $\mathrm{I} \& \mathrm{P}$ & $\mathrm{I} \& \mathrm{P}$ & I\&P & $\mathrm{I} \& \mathrm{P}$ & $\mathrm{I} \& \mathrm{P}$ & PA & $\sim$ & $\sim$ & $\sim$ & $\sim$ & $\sim$ & $\sim$ & $\sim$ & $\sim$ & $\sim$ \\
\hline ID & $\mathrm{I} \& \mathrm{P}$ & $I \& P$ & $I \& P$ & $\sim$ & $\sim$ & $\sim$ & $\sim$ & $\sim$ & $\sim$ & RI & $\sim$ & $\sim$ & I & I & I & I & I & I & $\mathrm{I}$ \\
\hline IL & $\mathrm{P}$ & $\mathrm{P}$ & $\mathrm{P}$ & $\mathrm{P}$ & $\mathrm{P}$ & $\mathrm{P}$ & $\mathrm{P}$ & $\mathrm{P}$ & $\mathrm{P}$ & SC & $\sim$ & $\mathrm{I} \& \mathrm{P}$ & $\mathrm{I} \& \mathrm{P}$ & $\mathrm{I} \& \mathrm{P}$ & $\mathrm{I} \& \mathrm{P}$ & $\mathrm{I} \& \mathrm{P}$ & $I \& P$ & $\mathrm{I} \& \mathrm{P}$ & $\mathrm{I} \& \mathrm{P}$ \\
\hline IN & $\mathrm{P}$ & $\mathrm{P}$ & $\mathrm{P}$ & $\mathrm{P}$ & $\mathrm{P}$ & $\mathrm{P}$ & $\mathrm{P}$ & $\mathrm{P}$ & $\mathrm{P}$ & D & $\sim$ & I & I & I & I & I & I & I & I \\
\hline $\mathrm{KS}$ & $\mathrm{I} \& \mathrm{P}$ & $\mathrm{I} \& \mathrm{P}$ & $\mathrm{I} \& \mathrm{P}$ & $\mathrm{I} \& \mathrm{P}$ & $\mathrm{I} \& \mathrm{P}$ & $\mathrm{I} \& \mathrm{P}$ & $\mathrm{I} \& \mathrm{P}$ & $\mathrm{I} \& \mathrm{P}$ & $\mathrm{I} \& \mathrm{P}$ & $\mathrm{TN}$ & $\sim$ & $\sim$ & $\sim$ & $\sim$ & $\sim$ & $\sim$ & $\sim$ & $\sim$ & $\sim$ \\
\hline $\mathrm{KY}$ & $\mathrm{I} \& \mathrm{P}$ & $\mathrm{I} \& \mathrm{P}$ & $\mathrm{I} \& \mathrm{P}$ & $\mathrm{I} \& \mathrm{P}$ & $\mathrm{I} \& \mathrm{P}$ & $\mathrm{I} \& \mathrm{P}$ & $\mathrm{I} \& \mathrm{P}$ & $\mathrm{I} \& \mathrm{P}$ & $\mathrm{I} \& \mathrm{P}$ & $\mathrm{TX}$ & $\mathrm{I} \& \mathrm{P}$ & $\mathrm{I} \& \mathrm{P}$ & $\mathrm{I} \& \mathrm{P}$ & $\mathrm{I} \& \mathrm{P}$ & $\mathrm{I} \& \mathrm{P}$ & $\mathrm{I} \& \mathrm{P}$ & $\mathrm{I} \& \mathrm{P}$ & $\mathrm{I} \& \mathrm{P}$ & $\mathrm{I} \& \mathrm{P}$ \\
\hline $\mathrm{LA}$ & $\sim$ & $\sim$ & $\sim$ & $\sim$ & $\sim$ & $\sim$ & $\sim$ & $\sim$ & $\sim$ & UT & $\mathrm{I} \& \mathrm{P}$ & $\mathrm{I} \& \mathrm{P}$ & $\mathrm{I} \& \mathrm{P}$ & $\mathrm{I} \& \mathrm{P}$ & $\mathrm{I} \& \mathrm{P}$ & $\mathrm{I} \& \mathrm{P}$ & $\mathrm{I} \& \mathrm{P}$ & $\mathrm{I} \& \mathrm{P}$ & $\mathrm{I} \& \mathrm{P}$ \\
\hline MA & $\sim$ & $\sim$ & $\sim$ & $\sim$ & $\sim$ & $\sim$ & $\sim$ & $\sim$ & $\sim$ & VA & $\mathrm{I} \& \mathrm{P}$ & $\mathrm{I} \& \mathrm{P}$ & $\mathrm{I} \& \mathrm{P}$ & $\mathrm{I} \& \mathrm{P}$ & $\mathrm{I} \& \mathrm{P}$ & $\mathrm{I} \& \mathrm{P}$ & $\mathrm{I} \& \mathrm{P}$ & $\mathrm{I} \& \mathrm{P}$ & $\mathrm{I} \& \mathrm{P}$ \\
\hline $\mathrm{MD}$ & $\sim$ & $\sim$ & $\sim$ & $\sim$ & $\sim$ & $\sim$ & $\sim$ & $\sim$ & $\sim$ & VT & $\sim$ & $\sim$ & $\sim$ & $\sim$ & $\sim$ & $\sim$ & $\sim$ & $\sim$ & $\sim$ \\
\hline $\mathrm{ME}$ & $\sim$ & $\sim$ & $\sim$ & $\sim$ & $\sim$ & $\sim$ & $\sim$ & $\sim$ & $\sim$ & WA & $\sim$ & $\sim$ & $\sim$ & $\sim$ & $\sim$ & $\sim$ & $\sim$ & $\sim$ & $\sim$ \\
\hline MI & $\sim$ & $\mathrm{I} \& \mathrm{P}$ & $\mathrm{I} \& \mathrm{P}$ & $\mathrm{I} \& \mathrm{P}$ & $\mathrm{I} \& \mathrm{P}$ & $\mathrm{I} \& \mathrm{P}$ & $\mathrm{I} \& \mathrm{P}$ & $\mathrm{I} \& \mathrm{P}$ & $\mathrm{I} \& \mathrm{P}$ & WI & $\sim$ & $\sim$ & $\sim$ & $\sim$ & $\sim$ & $\sim$ & $\sim$ & $\sim$ & $\sim$ \\
\hline $\mathrm{MN}$ & $\mathrm{I} \& \mathrm{P}$ & $\mathrm{I} \& \mathrm{P}$ & $\mathrm{I} \& \mathrm{P}$ & $\mathrm{I} \& \mathrm{P}$ & $\mathrm{I} \& \mathrm{P}$ & $\sim$ & $\sim$ & $\sim$ & $\sim$ & WV & $\sim$ & $\sim$ & $\sim$ & $\sim$ & $\sim$ & $\sim$ & $\sim$ & $\sim$ & $\sim$ \\
\hline $\mathrm{MO}$ & $\sim$ & $\sim$ & $\sim$ & $\sim$ & $\sim$ & $\sim$ & $\sim$ & $\sim$ & $\sim$ & WY & I\&P & I\&P & I\&P & $I \& P$ & I\&P & $\mathrm{I} \& \mathrm{P}$ & I\&P & I\&P & I\&P \\
\hline MS & $\mathrm{P}$ & $P$ & $\mathrm{P}$ & $\mathrm{P}$ & $\mathrm{P}$ & $\mathrm{P}$ & $\mathrm{P}$ & $\mathrm{P}$ & $\mathrm{P}$ & & & & & & & & & & \\
\hline
\end{tabular}

This table illustrates which states have provided statutory immunity (“I”), statutory audit privilege ("P”), both (“I\&P”), or neither during our sample period. Sources include Morandi (1998), U.S. EPA's Audit Policy website (http://www.epa.gov/region5/orc/audits/audit_apil.htm), and a private web service run by the Auditing Roundtable (http://www.auditing-roundtable.org). We resolved any inconsistencies by referring to the actual statutory language in LEXIS-NEXIS state statutory databases. 


\section{TABLE A2 \\ FEDERAL CIRCUIT COURT IDEOLOGY}

PROPORTION OF JUDGES ON EACH CIRCUIT NOMINATED

BY A DEMOCRATIC PRESIDENT, AVERAGE DURING 1990-1994

\begin{tabular}{cc}
\hline $\begin{array}{c}\text { U.S. Circuit } \\
\text { Court }\end{array}$ & $\begin{array}{c}\text { Percentage } \\
\text { nominated by a } \\
\text { Democrat }\end{array}$ \\
\hline 1 & $12.5 \%$ \\
2 & $38.9 \%$ \\
3 & $26.7 \%$ \\
4 & $37.5 \%$ \\
5 & $36.4 \%$ \\
6 & $35.3 \%$ \\
7 & $16.7 \%$ \\
8 & $30.8 \%$ \\
9 & $46.7 \%$ \\
10 & $41.7 \%$ \\
11 & $46.2 \%$ \\
D.C. & $42.9 \%$ \\
\hline
\end{tabular}

Source: Based on data from Zuk, Barrow, and Gryski (1996). 


\section{REFERENCES}

Anderson, Eric E., and Wayne K. Talley. 1995. "The Oil Spill Size of Tanker and Barge Accidents: Determinants and Policy Implications," 71 Land Economics 216-228.

Andreoni, J., B. Erard, and J. Feinstein. 1998. “Tax Compliance”, 36 Journal of Economic Literature 818-60.

Aoki, Kazumasu, and John W. Coiffi. 2000. 'Poles Apart: Industrial Waste Management Regulation and Enforcement in the United States and Japan,'in R.A. Kagan and L. Axelrod, eds., Regulatory Encounters. Berkeley: University of California Press.

Arlen, Jennifer, and Reinier Kraakman. 1997. "Controlling Corporate Misconduct: An Analysis of Corporate Liability Regimes," 72 New York University Law Review 687-779.

Ayres, Ian, and John Braithwaite. 1992. Responsive Regulation: Transcending the Deregulation Debate. New York: Oxford University Press.

Bardach, Eugene, and Robert A. Kagan. 1982. Going by the Book: The Problem of Regulatory Unreasonableness. Philadelphia: Temple University Press.

Becker, Gary. 1968. “Crime and Punishment: An Economic Approach”, 76 Journal of Political Economy 169-217.

Bedford, Christopher. 1996. Dirty Secrets: The Corporations' Campaign for an Environmental Audit Privilege. Takoma Park, Md.: Environmental Action Foundation. http://www.mapcruzin.com/scruztri/docs/r2.htm.

Braithwaite, John, and Toni Makkai. 1991. "Testing an Expected Utility Model of Corporate Deterrence," 25 Law \& Society Review 7-40.

Brehm, John, and James T. Hamilton. 1996. "Noncompliance in Environmental Reporting: Are Violators Ignorant, or Evasive, of the Law," 40 American Journal of Political Science 444-77.

Cohen, Mark A. 1987. "Optimal Enforcement Strategy to Prevent Oil Spills: An Application of a Principal-Agent Model with Moral Hazard," 30 Journal of Law and Economics 23-51.

—. 2000. 'Empirical Research on the Deterrence Effect of Environmental Monitoring and Enforcement," 30 Environmental Law Reporter 10245-252. 
Cox, James. 2004. "The Case Against a Judicially Created, Common-Law Self-Audit or Self-Evaluation Privilege Applicable to Environmental Cases," 51 Fordham Environmental Law Journal 1-30.

Dimento, Joseph F. 1989. “Can Social Science Explain Organizational Noncompliance with Environmental Law?’ 45 Journal of Social Issues 109-32.

Duggin, Sarah Helene. 2003. "Internal Corporate Investigations: Legal Ethics, Professionalism and the Employee Interview, 2003 Columbia Business Law Review 859-964.

Edelman, Lauren B. 1990. "Legal Environments and Organizational Governance: The Expansion of Due Process in the Workplace,” 95 American Journal of Sociology 1401-40.

Epple, Dennis, and Michael Visscher. 1984. "Environmental Pollution: Modeling Occurrence, Detection and Deterrence," 27 Journal of Law and Economics 29-60.

Fleder, John R. 1999. “A Voluntary Disclosure Program for FDA The Time Has Come”, 54 Food and Drug Law Journal 389-99.

Friedman, Lawrence. 1975. The Legal System: A Social Science Perspective. New York: Russell Sage Foundation.

Gardner, Allison F. 2003. "Beyond Compliance: Regulatory Incentives to Implement Environmental Management Systems,” 11 N.Y.U. Environmental Law Journal 662-710.

Gibbs, Jack. 1986. “Deterrence Theory and Research,” in G. Melton, ed., The Law as a Behavioral Instrument. Lincoln: University of Nebraska Press.

Goldsmith, Michael, and Chad W. King. 1997.'Policing Corporate Crime: The Dilemma of Internal Compliance Programs,"50 Vanderbilt Law Review 1-47.

Gray, Wayne, and John T. Scholz. 1991. "Analyzing the Equity and Efficiency of OSHA Enforcement,”13 Law \& Policy 185-214.

- 1993. "Does Regulatory Enforcement Work? A Panel Analysis of OSHA Enforcement,' 27 Law \& Society Review 177-213.

Gray, Wayne, and Ronald Shadbegian. 2005. 'When and Why Do Plants Comply? Paper Mills in the 1980s,' 27 Law \& Policy 238-61.

Grayson, E. Lynn, and Christina M. Landgraf. 1997. “EPA’s Audit Policy and State Audit Privilege Laws: Moving Beyond Command and Control?’ 27 Environmental Law Reporter 10243. 
Gunningham, Neil, and Peter Grabosky. 1998. Smart Regulation: Designing Environmental Policy. Oxford: Clarendon Press.

Gunningham, Neil, Robert A. Kagan, and Dorothy Thornton. 2003. Shades of Green: Business, Regulation, and Environment. Palo Alto, Calif.: Stanford University Press.

Gunningham, Neil, Dorothy Thornton, and Robert A. Kagan. 2005. "Motivating Management: Corporate Compliance in Environmental Protection,' 27 Law \& Policy 289-316.

Guthrie, Doug, and Louise Marie Roth. 1999. "The State, Courts, and Maternity Policies in U.S. Organizations: Specifying Institutional Mechanisms,” 64 American Sociological Review 41-63.

Hamilton, James T. 1993. "Politics and Social Costs: Estimating the Impact of Collective Action on Hazardous Waste Facilities,' 24 RAND Journal of Economics 101-25.

— 1 1999. 'Exercising Property Rights to Pollute: Do Cancer Risks and Politics Affect Plant Emission Reductions?' 18 Journal of Risk and Uncertainty 105-24.

Harrington, Winston. 1988. 'Enforcement Leverage When Penalties Are Restricted,” 37 Journal of Public Economics 29-53.

Helland, Eric. 1998. "The Enforcement of Pollution Control Laws: Inspections, Violations, and Self-Reporting,' 80 The Review of Economics and Statistics 14153.

Hunt, Terrell E., and Timothy A. Wilkins. 1992. 'Environmental Audits and Enforcement Policy,'16 The Harvard Environmental Law Review 365-427.

Innes, Robert. 1999a. 'Remediation and Self-Reporting in Optimal Law Enforcement”, 72 Journal of Public Economics 379-93.

—. 1999b. "Self-Policing and Optimal Law Enforcement When Violator Remediation Is Valuable," 7 Journal of Political Economy 1305-25.

—. 2000. "Self-reporting in Optimal Law Enforcement When Violators Have Heterogeneous Probabilities of Apprehension," 29 Journal of Legal Studies 287300.

.2001. 'Violator Avoidance Activities and Self-Reporting in Optimal Law Enforcement," 17 Journal of Law, Economics, and Organization 239-56. 
Kagan, Robert A., and John T. Scholz. 1984. "The Criminology of the Corporation and Regulatory Enforcement Styles,' in K. Hawkins and J.M. Thomas, eds., Enforcing Regulation. Boston, Mass.: Kluwer Academic.

Kagan, Robert A., Neil Gunningham, and Dorothy Thornton. 2003. ‘Explaining Corporate Environmental Performance: How Does Regulation Matter?’ 37 Law \& Society Review 51-90.

Kaisersatt, John P. 1996. "Criminal Enforcement as a Disincentive to Environmental Compliance: Is a Federal Environmental Audit Privilege the Right Answer?' 23 American Journal of Criminal Law 405-29.

Kaplow, Louis, and Steven Shavell. 1994. "Optimal Law Enforcement with SelfReporting of Behavior,' 102 Journal of Political Economy 583-606.

Kesan, Jay P. 2000. "Innovations in Environmental Policy: Encouraging Firms to Police Themselves: Strategic Prescriptions to Promote Corporate Self-Auditing,' University of Illinois Law Review 155-84.

King, Andrew A., and Michael J. Lenox. 2000. "Industry Self-Regulation Without Sanctions: The Chemical Industry's Responsible Care Program," 43 Academy of Management Journal 698-716.

Kuperan, K., and Jon G. Sutinen. 1998. "Blue Water Crime: Deterrence, Legitimacy, and Compliance in Fisheries,'32 Law \& Society Review 30930.

Laplante, Benoît, and Paul Rilstone. 1996. "Environmental Inspections and Emissions of the Pulp and Paper Industry in Quebec," 31 Journal of Environmental Economics and Management 19-36.

Lin, Albert C. 1996. “Application of the Continuing Violations Doctrine to Environmental Law,”23 Ecology Law Quarterly 723-78.

Lublin, David, and D. Stephen Voss. 2001. “Federal Elections Project.” American University, Washington, D.C. and the University of Kentucky. http://www.american.edu/academic.depts/spa/ccps/fepindex.html.

Magat, Wesley A., and W. Kip Viscusi. 1990. 'Effectiveness of the EPA's Regulatory Enforcement: The Case of Industrial Effluent Standards,” 33 Journal of Law and Economics 331-60.

Malik, A. 1993. "Self-Reporting and the Design of Policies for Regulating Stochastic Pollution,” 24 Journal of Environmental Economics and Management 241-57. 
Malmsheimer, Robert W., and Donald W. Floyd. 2004. 'U.S. Courts of Appeals Judges' Review of Federal Natural Resource Agencies' Decisions,' 17 Society and Natural Resources 533-46.

Medinger, Jason D. 2003. "Antitrust Leniency Programs: A Call for Increased Harmonization as Proliferating Programs Undermine Deterrence," 52 Emory Law Journal 1439-81.

Mendelhoff, John, and Wayne Gray. 2005. 'Inside OSHA’s Black Box: What Is the Link Between Inspections, Citations, and Reductions in Different Injury Type?'27 Law \& Policy 219-37.

Morandi, Larry. 1998. State Environmental Audit Laws and Policies: An Evaluation. Denver, Colo.: National Conference of State Legislatures.

Murray, Paula C. 1999. “Inching Toward Environmental Regulatory Reform ISO 14000: Much Ado About Nothing or a Reinvention Tool?' 37 American Business Law Journal 35-71.

Peterson, Melody, and Christopher Drew. 2003. "The Slaughterhouse Gamble: The Risk of Self-Policing; New Safety Rules Fail to Stop Tainted Meat.” New York Times A1 (October 3).

Pfaff, Alexander S.P., and Chris W. Sanchirico. 2000. "Environmental Self-Auditing: Setting the Proper Incentives for Discovery and Correction of Environmental Harm,’16 Journal of Law, Economics, and Organization 189-208.

—. 2004. "Big Field, Small Potatoes: An Empirical Assessment of EPA's Self-Audit Policy”, 23 Journal of Policy Analysis and Management 415-32.

Rechtschaffen, Clifford. 2004. "Enforcing the Clean Water Act in the Twenty-First Century: Harnessing the Power of the Public Spotlight,' 55 Alabama Law Review 775-814.

Rees, Joseph V. 1994. Hostages of Each Other: The Transformation of Nuclear Safety Since Three Mile Island. Chicago: University of Chicago Press.

Revesz, Richard L. 2001. "Federalism and Environmental Regulation: A Public Choice Analysis,"115 Harvard Law Review 553-641.

Rivera, Jorge, and Peter de Leon. 2004. 'Is Greener Whiter? The Sustainable Slopes Program and the Voluntary Environmental Performance of Western Ski Areas,” 32 Policy Studies Journal 417-37. 
Ross, H. Laurence. 1982. 'Interrupted Time Series Studies of Deterrence of Drinking and Driving,' in J. Hagan, ed., Deterrence Reconsidered: Methodological Innovations. Beverly Hills, Calif.: Sage Publications.

Scholz, John T. 1984. "Cooperation, Deterrence, and the Ecology of Regulatory Enforcement”, 18 Law \& Society Review 179-224.

Shapiro, Marc. 2005. 'Equity and Information: Information Regulation, Environmental Justice, and Risks from Toxic Chemicals," 24 Journal of Policy Analysis and Management 373-98.

Shimshack, Jay P., and Michael B. Ward. 2005. "Regulator Reputation, Enforcement, and Environmental Compliance," 50 Journal of Environmental Economics and Management 519-40.

Spence, David B. 2001. "The Shadow of the Rational Polluter: Rethinking the Role of Rational Actor Models in Environmental Law,” 89 California Law Review 917-98.

Spence, David B., and Paula Murray. 1999. “The Law, Economics, and Politics of Federal Preemption Jurisprudence: A Quantitative Analysis’ 87 California Law Review 1125-06.

Thornton, Dorothy, Neil Gunningham, and Robert A. Kagan. 2005. “General Deterrence and Corporate Environmental Behavior’’ 27 Law \& Policy 262-88.

U.S. EPA. 1992. "Identifying the Regulated Community and Establishing Program Priorities," in Principles of Enforcement. Washington, D.C.: U.S. Environmental Protection Agency. EPA Number www.inece.org/enforcementprinciples.html.

—. 1995. "Incentives for Self-Policing: Discovery, Disclosure, Correction and Prevention of Violations,'60 Federal Register 66706-712.

— 1999.'Evaluation of 'Incentives for Self-Policing: Discovery, Disclosure, Correction and Prevention of Violations' Policy Statement, Proposed Revisions and Request for Public Comment,” 64 Federal Register 26745-56.

U.S. GAO. 2000. Environmental Protection: More Consistency Needed Among EPA Regions in Approach to Enforcement. Washington, D.C.: United States General Accounting Office (Report GAO/RCED-00-108).

Wasserman, Cheryl E. 1990."An Overview of Compliance and Enforcement in the United States: Philosophy, Strategies, and Management Tools," First International Enforcement Workshop Proceedings. Utrecht, The Netherlands International 
Network for Environmental Compliance and Enforcement (May), http://www.inece.org/1stvol1/1stTOC.htm.

Welch, Eric W., Allan Mazur, and Stuart Bretschneider. 2000. 'Voluntary Behavior by Electric Utilities: Levels of Adoption and Contribution of the Climate Challenge Program to the Reduction of Carbon Dioxide," 19 Journal of Policy Analysis and Management 407-425.

Winter, Soeren C., and Peter J. May. 2001. "Motivation for Compliance with Environmental Regulations," 20 Journal of Policy Analysis \& Management 67598.

Woodall, Mark (Sierra Club Audit Privilege Task Force). 1997."Secrecy Bills Derailed in States," 4 The Planet, www.sierraclub.org/planet/199701/states.asp.

Zuk, Gary, Deborah J. Barrow, and Gerard S. Gryski. 1996. "A Multi-User Database on the Attributes of U.S. Appeals Court Judges, 1801-1994 [Computer file]. 1st ICPSR version." Gary Zuk, Deborah J. Barrow, \& Gerard S. Gryski, Auburn University [producers], Ann Arbor, Mich.: Inter-university Consortium for Political and Social Research [distributor], 1997. 


\section{TABLE 1 \\ NUMBER OF FACILITIES THAT DISCLOSED VIOLATIONS TO THE AUDIT POLICY, 1997-2003}

\begin{tabular}{|c|c|c|c|}
\hline & $\begin{array}{c}\text { (1) } \\
\text { All facilities }\end{array}$ & $\begin{array}{c}\text { (2) } \\
\text { All facilities }\end{array}$ & $\begin{array}{c}\text { (3) } \\
\text { Our sample }\end{array}$ \\
\hline 1997 & 457 & 153 & 40 \\
\hline 1998 & 950 & 251 & 54 \\
\hline 1999 & 990 & 412 & 113 \\
\hline 2000 & Not available & 773 & 221 \\
\hline 2001 & 1754 & 603 & 175 \\
\hline 2002 & Not available & 777 & 83 \\
\hline 2003 & 614 & 520 & 66 \\
\hline Total & & 3489 & 752 \\
\hline
\end{tabular}

Sources: Data in column 1 were obtained from various U.S. EPA reports and newsletters that provide updates on participation in the Audit Policy. The other columns reflect facility-level data we obtained from three sources via Freedom of Information Act requests: the U.S. EPA Integrated Compliance Information System (ICIS) database, the (hardcopy) U.S. EPA Audit Policy Docket, and lists of facilities that disclosed under the Audit Policy in response to the Compliance Incentive Programs. According to discussions with U.S. EPA, the disparities between the database we constructed from U.S. EPA databases and documents and U.S. EPA's own aggregate figures are likely due to several factors, including: (1) their reports typically refer to fiscal years rather than calendar years; (2) U.S. EPA does not always enter facility-level data into their databases when a corporation simultaneously discloses tens or hundreds of violations across multiple facilities; and (3) data coding errors or omissions.

Column 3 refers to the sample used in our empirical analysis: facilities that report data to the U.S. EPA Toxic Release Inventory (TRI) program and are subject to hazardous waste regulations pursuant to the Resource Conservation and Recovery Act (RCRA) and air regulations pursuant to the Clean Air Act (CAA). 
TABLE 2

VARIABLE DEFINITIONS AND SUMMARY STATISTICS

\begin{tabular}{|c|c|c|c|c|}
\hline Variable & Definition & Mean & SD & $\begin{array}{c}\text { Min Max } \\
\text { (For dummies, } \\
\text { number coded 1) }\end{array}$ \\
\hline $\begin{array}{l}\text { Self-disclosure via the Audit } \\
\text { Policy }\end{array}$ & $\begin{array}{l}\text { t Dummy coded } 1 \text { in a year when a facility discloses a } \\
\text { violation under the U.S. EPA Audit Policy }\end{array}$ & 0.007 & 0.082 & 752 \\
\hline RCRA inspections & $\begin{array}{l}\text { Number of regulatory inspections per year pertaining } \\
\text { to the U.S. Resource Conservation and Recovery Act }\end{array}$ & 0.328 & 0.763 & 0 \\
\hline CAA inspections & $\begin{array}{l}\text { Number of regulatory inspections per year pertaining } \\
\text { to the U.S. Clean Air Act }\end{array}$ & 0.620 & 0.793 & 0 \\
\hline$\overline{\text { RCRA violations }}$ & $\begin{array}{l}\text { Number of violations per year pertaining to the U.S. } \\
\text { Resource Conservation and Recovery Act a facility } \\
\text { was cited with by a regulator }\end{array}$ & 0.308 & 1.159 & 0 \\
\hline CAA violations & $\begin{array}{l}\text { Number of violations per year pertaining to the U.S. } \\
\text { Clean Air Act a facility was cited with by a regulator }\end{array}$ & 0.039 & 0.194 & 3 \\
\hline Any enforcement actions & $\begin{array}{l}\text { Dummy coded } 1 \text { in a year when a facility was } \\
\text { subjected to an enforcement action by a regulator }\end{array}$ & 0.020 & 0.138 & 2,159 \\
\hline $\begin{array}{l}\text { Compliance Incentive } \\
\text { Program target and National } \\
\text { Priority Sector }\end{array}$ & $\begin{array}{l}\text { Dummy coded } 1 \text { in a year when a facility was among } \\
\text { those targeted by a U.S. EPA Compliance Incentive } \\
\text { Program and whose industry was a U.S. EPA } \\
\text { National Priority Sector }\end{array}$ & 0.005 & 0.072 & 574 \\
\hline $\begin{array}{l}\text { Compliance Incentive } \\
\text { Program target but not } \\
\text { National Priority Sector }\end{array}$ & $\begin{array}{l}\text { Dummy coded } 1 \text { in a year when a facility was among } \\
\text { those targeted by a U.S. EPA Compliance Incentive } \\
\text { Program but whose industry was not a U.S. EPA } \\
\text { National Priority Sector }\end{array}$ & 0.005 & 0.067 & 499 \\
\hline $\begin{array}{l}\text { National Priority Sector but } \\
\text { not Compliance Incentive } \\
\text { Program target }\end{array}$ & $\begin{array}{l}\text { Dummy coded } 1 \text { in a year when a facility's industry } \\
\text { was named as U.S. EPA National Priority Sector but } \\
\text { the facility was not targeted by a Compliance } \\
\text { Incentive Program }\end{array}$ & 0.135 & 0.342 & 14,933 \\
\hline $\begin{array}{l}\text { Compliance Incentive } \\
\text { Program target in any prior } \\
\text { year (dummy) }\end{array}$ & $\begin{array}{l}\text { Dummy coded } 1 \text { in all years after a facility was first } \\
\text { targeted by a Compliance Incentive Program }\end{array}$ & 0.026 & 0.159 & 2,859 \\
\hline State audit privilege & $\begin{array}{l}\text { Dummy coded } 1 \text { in years when a facility's state } \\
\text { provides statutory audit privilege }\end{array}$ & 0.455 & 0.498 & 50,321 \\
\hline State immunity & $\begin{array}{l}\text { Dummy coded } 1 \text { in years when a facility's state } \\
\text { provides statutory immunity }\end{array}$ & 0.330 & 0.470 & 36,476 \\
\hline $\begin{array}{l}\text { Log population density in } \\
2000\end{array}$ & $\begin{array}{l}\text { Population density during } 2000 \text { of a facility's Census } \\
\text { Tract }\end{array}$ & 2.359 & 0.082 & $2.303 \quad 2.811$ \\
\hline $\begin{array}{l}\text { Log per capita income in } \\
1999\end{array}$ & $\begin{array}{l}\text { Per capita income in } 1999 \text { of a facility’s Census } \\
\text { Tract }\end{array}$ & 9.724 & 0.866 & 0.00012 .055 \\
\hline $\begin{array}{l}\text { Voter turnout in } 2000 \\
\text { (county) }\end{array}$ & $\begin{array}{l}\text { Percent of population who voted for U.S. president } \\
\text { in the } 2000 \text { elections in a facility's county }\end{array}$ & 0.519 & 0.077 & 0.0531 .000 \\
\hline $\begin{array}{l}\text { Log facility sub-industry } \\
\text { revenues in } 1997 \text { (SIC4) }\end{array}$ & $\begin{array}{l}\text { Average revenues per facility in } 1997 \text { in a facility's } \\
\text { 4-digit SIC Code }\end{array}$ & 9.637 & 1.199 & 6.83214 .627 \\
\hline $\begin{array}{l}\text { Federal Circuit Court } \\
\text { ideology (U.S. Circuit) }\end{array}$ & $\begin{array}{l}\text { Percent of U.S. Circuit Court's judges in 1990-94 } \\
\text { appointed by Democratic presidents in a facility's } \\
\text { U.S. Circuit }\end{array}$ & 0.324 & 0.102 & $\begin{array}{ll}0.125 & 0.467\end{array}$ \\
\hline
\end{tabular}

Note: 110,611 facility-year observations. RCRA = Resource Conservation and Recovery Act; CAA = Clean Air Act 
TABLE 3

\section{CORRELATIONS}

\begin{tabular}{|c|c|c|c|c|c|c|c|c|c|c|c|c|c|c|c|c|c|}
\hline & & 1 & 2 & 3 & 4 & 5 & 6 & 7 & 8 & 9 & 10 & 11 & 12 & 13 & 14 & 15 & 16 \\
\hline 1 & Self-disclosure via the Audit Policy (dummy) & 1.00 & & & & & & & & & & & & & & & \\
\hline 2 & RCRA inspections 1 year ago & 0.02 & 1.00 & & & & & & & & & & & & & & \\
\hline 3 & CAA inspections 1 year ago & 0.02 & 0.12 & 1.00 & & & & & & & & & & & & & \\
\hline 4 & RCRA violations 1 year ago & 0.01 & 0.55 & 0.06 & 1.00 & & & & & & & & & & & & \\
\hline 5 & CAA violations 1 year ago & 0.01 & 0.06 & 0.16 & 0.03 & 1.00 & & & & & & & & & & & \\
\hline 6 & Any enforcement actions 1 year ago (dummy) & 0.04 & 0.07 & 0.04 & 0.04 & 0.09 & 1.00 & & & & & & & & & & \\
\hline 7 & CIP target and National Priority Sector (dummy) & 0.03 & 0.05 & 0.02 & 0.02 & 0.02 & 0.02 & 1.00 & & & & & & & & & \\
\hline 8 & CIP target but not National Priority Sector (dummy) & 0.14 & 0.01 & 0.01 & 0.01 & 0.01 & 0.01 & 0.00 & 1.00 & & & & & & & & \\
\hline 9 & National Priority Sector but not CIP target (dummy) & -0.01 & 0.08 & 0.03 & 0.04 & 0.05 & 0.04 & -0.03 & -0.03 & 1.00 & & & & & & & \\
\hline 10 & CIP target in any prior year (dummy) & 0.07 & 0.07 & 0.03 & 0.03 & 0.02 & 0.14 & 0.17 & -0.01 & -0.01 & 1.00 & & & & & & \\
\hline 11 & State audit privilege (dummy) & -0.01 & -0.02 & -0.08 & 0.04 & -0.04 & 0.00 & -0.01 & -0.01 & 0.00 & -0.01 & 1.00 & & & & & \\
\hline 12 & State immunity (dummy) & 0.01 & 0.03 & -0.10 & 0.04 & 0.00 & 0.02 & 0.00 & 0.00 & 0.02 & 0.00 & 0.60 & 1.00 & & & & \\
\hline 13 & Log population density in 2000 & -0.01 & -0.06 & -0.10 & -0.03 & -0.01 & 0.00 & 0.01 & -0.01 & 0.06 & 0.00 & -0.07 & -0.03 & 1.00 & & & \\
\hline 14 & Log per capita income in 1999 & 0.00 & -0.01 & -0.03 & -0.01 & -0.01 & 0.00 & -0.01 & 0.01 & -0.01 & 0.00 & -0.01 & -0.01 & 0.01 & 1.00 & & \\
\hline 15 & Voter turnout in 2000 & 0.00 & -0.04 & -0.09 & -0.01 & -0.04 & 0.00 & 0.00 & 0.01 & -0.01 & 0.01 & 0.00 & $0.05-$ & -0.04 & 0.16 & 1.00 & \\
\hline 16 & Log facility sub-industry revenues in 1997 & 0.04 & 0.10 & 0.14 & 0.02 & 0.10 & 0.06 & 0.03 & 0.05 & 0.07 & 0.09 & -0.01 & $0.03-$ & -0.10 & -0.02 & -0.01 & 1.00 \\
\hline 17 & Federal Circuit Ideology & 0.01 & 0.07 & 0.11 & 0.04 & 0.03 & 0.01 & 0.00 & 0.01 & 0.00 & 0.01 & -0.16 & $0.14-$ & -0.14 & -0.10 & -0.26 & 0.08 \\
\hline
\end{tabular}

Note: 110,611 facility-year observations. RCRA = Resource Conservation and Recovery Act; CAA = Clean Air Act; CIP = Compliance Incentive Program 
TABLE 4

WHO PARTICIPATES IN THE AUDIT POLICY?

\section{Dependent variable: Self-disclosure via the Audit Policy}

\begin{tabular}{|c|c|c|c|c|}
\hline & & $\begin{array}{c}\text { (A) } \\
\text { Probit } \\
\text { coefficient }\end{array}$ & $\begin{array}{c}\text { (B) } \\
\text { Marginal } \\
\text { effect }\end{array}$ & $\begin{array}{c}(\mathrm{C}) \\
\text { Marginal } \\
\text { effect to } \\
\text { baseline } \\
\text { probability }\end{array}$ \\
\hline \multirow[t]{5}{*}{$\begin{array}{l}\text { Specific } \\
\text { deterrence }\end{array}$} & RCRA evaluations 1 year ago & $\begin{array}{c}0.048 \\
{[0.021]^{* *}}\end{array}$ & 0.0005 中 & $14 \%$ \\
\hline & CAA inspections 1 year ago & 0.038 & $0.0004 \%$ & $11 \%$ \\
\hline & RCRA violations 1 year ago & $\begin{array}{l}-0.005 \\
{[0.013]}\end{array}$ & $-0.0001 \%$ & $-1 \%$ \\
\hline & CAA violations 1 year ago & $\begin{array}{c}0.040 \\
{[0.066]}\end{array}$ & $0.0004 \%$ & $12 \%$ \\
\hline & Any enforcement actions 1 year ago & $\begin{array}{l}0.276 \\
{[0.063] * * *}\end{array}$ & 0.0044 & $118 \%$ \\
\hline \multirow[t]{3}{*}{$\begin{array}{l}\text { General } \\
\text { deterrence }\end{array}$} & CIP target \& National Priority Sector & $\begin{array}{l}0.365 \\
{[0.124]^{* * *}}\end{array}$ & 0.0067 & $179 \%$ \\
\hline & CIP target but not National Priority Sector & $\begin{array}{l}1.358 \\
{[0.076]^{* * *}}\end{array}$ & 0.0894 & $2382 \%$ \\
\hline & National Priority Sector but not CIP target & $\begin{array}{l}-0.047 \\
{[0.059]}\end{array}$ & -0.0005 & $-13 \%$ \\
\hline Information & CIP target in any prior year & {$[0.528]^{* * *}$} & 0.0118 & $315 \%$ \\
\hline \multirow[t]{2}{*}{$\begin{array}{l}\text { Statutory } \\
\text { provisions }\end{array}$} & State audit privilege & $\begin{array}{l}-0.005 \\
{[0.057]}\end{array}$ & -0.0001 & $-1 \%$ \\
\hline & State immunity & $\begin{array}{c}0.073 \\
{[0.052]}\end{array}$ & 0.0008 & $22 \%$ \\
\hline \multirow[t]{8}{*}{ Controls } & Log population density in 2000 & $\begin{array}{c}0.031 \\
{[0.222]}\end{array}$ & 0.0003 & $9 \%$ \\
\hline & Log per capita income in 1999 & $\begin{array}{l}-0.007 \\
{[0.019]}\end{array}$ & -0.0001 & $-2 \%$ \\
\hline & Voter turnout in 2000 & $\begin{array}{c}0.311 \\
{[0.258]}\end{array}$ & 0.0035 & $93 \%$ \\
\hline & Log facility revenues in 1997 & $\begin{array}{l}0.101 \\
{[0.019]^{* * *}}\end{array}$ & 0.0012 & $31 \%$ \\
\hline & Federal Circuit Court ideology & $\begin{array}{l}0.035 \\
{[0.263]}\end{array}$ & 0.0004 & $11 \%$ \\
\hline & Industry fixed-effects & Included $* * *$ & & \\
\hline & Year fixed-effects & Included $* * *$ & & \\
\hline & EPA Region fixed-effects & Included*** & & \\
\hline \multicolumn{2}{|c|}{ Observations (facility-years) } & 110,611 & & \\
\hline \multicolumn{2}{|c|}{$\begin{array}{l}\text { Facilities } \\
\text { Log likelihood intercept only }\end{array}$} & 17,464 & & \\
\hline \multicolumn{2}{|c|}{ Log likelihood intercept only } & -4502.70 & & \\
\hline \multicolumn{2}{|c|}{ Log likelihood full model } & -3899.28 & & \\
\hline \multicolumn{2}{|c|}{$\begin{array}{l}\text { Likelihood ratio } \\
\text { McFadden's pseudo } R \text {-squared }\end{array}$} & $1206.84^{* * *}$ & & \\
\hline \multicolumn{2}{|c|}{$\begin{array}{l}\text { McFadden's pseudo } R \text {-squared } \\
\text { Probability of disclosure evaluated at mean of all variables }\end{array}$} & $\begin{array}{l}0.13 \\
0.0038\end{array}$ & & \\
\hline
\end{tabular}

\footnotetext{
"Marginal effect" is the change in the probability of adoption, evaluated at the mean all variables, based on an infinitesimal change in each continuous independent variable, a unit change in each count variable (denoted \&), or a discrete change in each dummy variable (denoted $\bullet$ ). "Marginal effect to baseline probability" is the marginal effect as a proportion of the probability of disclosure evaluated at mean of all variables. Brackets contain robust standard errors clustered by facility. $* * * p<0.01 ; * *$ $p<0.05 ; * p<0.10$. All specifications include dummy variables to control for industry (2-digit SIC Codes), EPA Region, and Year, and the proportion of U.S. Circuit Court judges appointed by a Democratic president. RCRA = Resource Conservation and Recovery Act; CAA = Clean Air Act; CIP = Compliance Incentive Program
} 